\title{
Metaqueerfory w naszym życiu
}

https://doi.org/10.51897/interalia/GFIB3085

Piotr Sobolczyk

Instytut Badań Literackich PAN

Recenzja: Katarzyna Lisowska, Metaforyczność w dyskursie genderowym polskiego literaturoznawstwa po 1989 roku, Universitas, Kraków 2019.

Z pewną taką śmiałością zabieram głos w sprawie rozprawy Katarzyny Lisowskiej Metaforyczność w dyskursie genderowym polskiego literaturoznawstwa po 1989 roku, której jestem jednym z bohaterów. Po pierwsze, w procedowaniu - jeśli można tak się wyrazić - tej pracy brali udział także inni jej bohaterki i bohaterzy: Inga Iwasiów, w książce najczęściej cytowana spośród przedstawicieli nurtu genderowego, odróżnionego od studiów gejowsko-lesbijskich i queer, o czym dalej, była recenzentką doktorskiej wersji tej rozprawy; Wojciech Śmieja, bohater zarówno przypisany do studiów gejowskolesbijskich, jak i queer, a także do studiów nad męskością (w niewielkim stopniu obecnych w książce, ale niepominiętych), był recenzentem wydawniczym wersji książkowej. Chcę z tego wyciągnąć pewien ogólniejszy wniosek, a może raczej upublicznić - udyskursywnić - pewną informację, zapewne oczywistą dla dzisiejszych aktantów teatru nauki specjalizujących się w tej części badań literackich: do niedawna (rozprawę doktorską obroniła Lisowska w 2017) nie było jeszcze tylu osób z tytułami uprawniającymi do recenzowania doktoratów specjalizujących się „plus minus” (zaraz to wytłumaczę) w tej problematyce, by dało się uniknąć podwójnej roli aktora i aktanta w opisie obserwacji drugiego i trzeciego stopnia. Najwięcej uprawomocnionych osób wywodziło się - do niedawna - z nurtu feministycznego. Stąd do przewodów doktorskich czy habilitacyjnych powoływano osoby z nieco rozmytego i shomogenizowanego zbioru "uwrażliwienia na płeć" (oraz, być może, seksualność), pomimo że większość samych aktantów, jak sądzę, jest doskonale świadoma różnic metodologicznych, stylistycznych, a niekiedy nawet i etycznych pomiędzy tymi nurtami i niebezproblematycznej przekładalności pomiędzy nimi. Potrzeba jest matką, dlatego i feminizm bywał tu matką, rozumiem więc takie wybory motywowane potrzebą i brakiem, natomiast osobiście sądzę, że większym problemem, choć nie aż tak znów wielkim, było wskazywanie aktantów z innych nurtów jakoś pokrewnych, aniżeli wybór osób będących równocześnie bohater(k)ami pracy. Po drugie, jakkolwiek w polskiej humanistyce praktycznie nie zaistniała problematyzacja kategorii czy metody badawczej zwanej autoetnografią, a mająca tradycję sięgającą co najmniej lat 70. - mówię to bez pretensji a czysto diagnostycznie - a w polskie myślenie literaturoznawcze mocno wkorzenione są pozytywistyczne z ducha a wzmocnione silnym paradygmatem strukturalistycznym kategorie dystansu między „podmiotem” a „przedmiotem”, tudzież (skalarna) niechęć do biografizmu i psychologizowania, jak i (niezbyt skalarna i mocna) do mieszania nauki o literaturze z literaturą - to osoba obeznana w tradycjach światowych zarówno feminizmu, jak i - przede wszystkim - queer doskonale orientuje się, że autoetnografia czy choćby momenty (wtręty?) autoetnograficzne były tam stosowane z powodzeniem, a też i przyjmowane ze zrozumieniem, a bez szoku. Opis polskiego dyskursu i autoetnografii w nim skądinąd 
będzie kiedyś niezmiernie ciekawym zadaniem badawczym. Po trzecie, Lisowska zwróciła uwagę także na takie momenty autoetnograficzne w badanych dyskursach, choć nienazywając ich tym pojęciem, właśnie jako na momenty, mówiąc o "prywatności” i „konfesyjności” (oraz o szerszej poststrukturalistycznej kategorii "upodmiotowienia języka”), czyli pojęciami lepiej zadomowionymi u nas, ale też odsyłającymi do opisów literatury ("nowa prywatność", "konfesyjność w autobiografizmie" itp.), podczas gdy dla fetyszystów „naukowości” samo brzmienie pojęcia „autoetnografia” obiecuje rozkosz uprawomocnienia, definicyjności, instytucjonalizacji. Być może wręcz różnica między „prywatnością + konfesyjnością" a „autoetnografią" stanowi element rozróżnienia feminizmu od queer.

Rzeczywiście, o ile wydawane w zachodnich ośrodkach publikacje poświęcone męskiej i kobiecej twórczości homotekstualnej często zbliżają się do konfesji, o tyle w rodzimych studiach nawiązujących do krytyki gejowskiej i lesbijskiej trudniej znaleźć wypowiedzi wskazujące na osobistą korzyść, jaką autorowi lub autorce przynosi badanie literatury (nieco inaczej dzieje się w tekstach pisanych z perspektywy queerowej, o czym piszę dalej), lub odwołujące się do biografii piszącego/ piszącej,

pisze Lisowska (2019: 258-259). Otóż właśnie, problematyczna dla mnie kategoria "osobistej korzyści” mniej dziwi w studiach gejowsko-lesbijskich (osobistą korzyścią jest np. budowanie większej widoczności sławnych osób LGBTQ w przestrzeni publicznej - jest to model, który, przypomnę, mocno krytykowałem), a Lisowska wywiodła ją za Katarzyną Majbrodą z myśli Iwasiów (Majbroda, 2013: 353) ${ }^{1}$. Nie chodzi mi w tym momencie o skonstruowanie kilkupiętrowej polemiki z Iwasiów via Majbroda (et Lisowska), tylko o spostrzeżenie, że kategoria "osobistej korzyści” nie przystaje do autoetnografii, ani też, jak mi się zdaje (i jak próbowałem sam to uprawiać) do queer: nie chodzi o „autoterapię" (jak pisze Majbroda o feminizmie; jak miałbym to przetłumaczyć na queerowość, że pisząc interpretacje queerowości Białoszewskiego przepracowuję traumę własnej homoseksualności?!, ergo prawem entymematu jeśli nie mam traumy, to nie badam?!), ani o korzyść polityczną czy społeczną, chodzi o uprawomocnione wyzyskanie autonarracji, wiedzy o samym sobie, wglądu w siebie, rozpoznania własnego zachowania aktanta w interakcji społecznej i opisania go z perspektywy drugiego i trzeciego stopnia. Wiedzy o własnym doświadczeniu jako kobieta, mężczyzna, osoba nienormatywna, heteroseksualna ale zajmująca się nienormatywnością itd. Jest to wiedza jakościowo inna, ale operacyjna i w związku z tym staje się uprawomocniona na równi z cytatem z jakiejś książki, gdzie ktoś opisał podobne doświadczenie. Mówiąc jeszcze inaczej, bierze w nawias pewną hipokryzję czy fikcję (nie wiem, jak to dobrze określić), kiedy chcąc w dyskursie "naukowym” powiedzieć o czymś, co jest najzupełniej dla nas oczywiste w kontekście naszego doświadczenia życiowego, aby móc to włączyć w obręb dyskursu, przeszukujemy gorączkowo dzieła literackie i opracowania w poszukiwaniu opisu podobnego doświadczenia, które ewentualnie potem można "naciągnąć”, jeśli różni się w czymś od naszego, na które chcielibyśmy się powołać, lecz strażnicy dyskursu bronią². Mnie na przykład, aby

${ }^{1}$ Chodzi o książkę I. Iwasiów, Parafrazy i reinterpretacje. Wykłady z teorii i praktyki czytania, Wyd. Naukowe Uniwersytetu Szczecińskiego, Szczecin 2004.

2 Parafrazując stary dowcip literaturoznawczy: „- skąd autor rozprawy wie, że kwiaty pachną? - czytałem o tym w rozprawie X, a także Yksiński zajął w tej sprawie mocne stanowisko". Mapa obszarów doświadczenia codziennego / potocznego, o 
wykonać gest jakże meta- i auto-, zarzucano, że posłużyłem się w tym czy innym miejscu terminami zaklasyfikowanymi jako "slang gejowski" ${ }^{3}$. Lisowska dodaje w bodaj jednym miejscu jakkolwiek problematyzującym zderzenie czy spięcie między o d m i e n n o ś c i ą dyskursu (głównie) queerowego a ( $\mathrm{z}$ a) s t a ł o ś c i ą dyskursu polskiej nauki o literaturze: „Być może sytuacja ta wynika z konserwatywnego charakteru polskiej tradycji, lub, co równie prawdopodobne, długiej dominacji, niezakładającego eksponowania jednostkowego głosu badacza/badaczki, paradygmatu strukturalistyczno-formalistycznego w literaturoznawstwie" (Lisowska, 2019: 259)4. Badaczka jednak znalazła świetny a rodzimy termin - „narracja pierwszoqueerosobowa”. Choć nie pokrywa się on ściśle z projektem autoetnografii, to jest jakoś pokrewny. Tomasz Sikora i Rafał Majka podkreślają stronę subwersywną, wywrotową, "zaangażowaną" takich gestów, charakteryzując styl owej narracji jako „swobodny, często (w odczuciu niektórych może nazbyt) osobisty (...) oparty niekiedy na własnych doświadczeniach, a więc (osobiście) zaangażowany (...) emanuj[ący] 'wywrotowym', słusznym gniewem" (Sikora i Majka, 2012: 604). Rzecz w tym, że osobiste zaangażowanie nie musi się realizować wyłącznie jako gniew; odwołanie do osobistego doświadczenia nie musi służyć tak zdefiniowanemu zaangażowaniu. Autoetnografia przewiduje tu możliwe różne strategie. Nie mówię teraz w kontrze do Sikory i Majki ani też oczywiście Lisowskiej, zgadzając się z jej dalszym komentarzem o obecnej w queer (i, dodajmy, także innych nurtach po-strukturalistycznych) potrzebie

którym "można" wspomnieć, oraz czarne obszary, których tykać „nie wolno", nie jest przecież wykreślona, stanowi fantazmatyczny, "milcząco zakładany”, „powszechnie podzielany (rozpoznawany)” itd. punkt odniesienia, jakieś "nieświadome" nauki (tu: o literaturze). Skądinąd historycznie zmienny opis takiej mapy co wolno, jak wolno i jak autorzy dyskursywizowali owe niewypowiedzenia, byłby także bardzo interesującym przedsięwzięciem z zakresu metaliteraturoznawstwa. Mam wrażenie, że w interesującym nas zakresie seksualności (bardziej niż płciowości) działają dwa tabu, mówienia o seksualności w ogóle i „jako takiej", a sekundarnie jeszcze bardziej napiętnowane mówienie o seksualności nienormatywnej; z drugiej strony działa także, jak sądzę, filtr - względem samej teorii queer zewnętrzny uznający, że wszelkie badania nienormatywności, wszelkie wypowiedzi na jej temat, w tym wypadku autokomentarze, dotyczą właściwie seksualności (a nie np. afektów, emocjonalności, polityczności itd.) i jako takie automatycznie kwalifikowane są jako naruszanie tabu - tej seksualności "jako takiej”. Jeśli trafnie rekonstruuję, to jest to mechanizm maskowania pewnej postaci homofobii z wyzyskaniem seksofobii (innymi słowy, mówiąc bardzo prosto - jesteś gejem / lesbijką / trans / bi - mniej ci wolno).

${ }^{3}$ Przy czym konstruktor zarzutu nie zaznaczył, czy danego wyrażenia użyłem „od siebie”, czy też komentując tekst literacki, gdzie zostało użyte, a nawet wręcz je parafrazując - to jedno; drugie - nie dodał, że w polszczyźnie ani oficjalnej słownikowej, ani też "naukowej", nie istnieje żaden odpowiednik, który w mniejszym stopniu odsyłałby do "doświadczenia potocznego", to znaczy - mojego konkretnie doświadczenia.

${ }^{4}$ To, co nie zostało $w$ tym kontekście powiedziane w książce, a jest może jakąś differentia specifica polskiego dyskursu przede wszystkim queer, ale też feministycznego, a co w porównaniu z amerykańskimi biografiami badaczy queer staje się jeszcze bardziej widoczne, to dwoistość ról uczonego/uczonej i artysty/artystki. O ile to musi być dwoistość. Proszę zwrócić uwagę: obecna w książce głównie jako genderystka, ale przecież także feministka Inga Iwasiów jest pisarką (dodajmy też przykłady Anny Nasiłowskiej, Brygidy Helbig, które nie są co prawda bohaterkami tej książki); Izabela Filipiak (obecnie Morska), tu jako przedstawicielka queer, ale też przecież feministka, jest pisarką; Tomasz Kitliński jest autorem kolaży i innych działań wizualnych, a także performerem; Piotr Seweryn Rosół (jakkolwiek w książce nieobecny) jest performerem i kuratorem sztuki; Tomasz Kaliściak debiutował tomem wierszy; Wojciech Śmieja jest reportażystą; ja, cóż, robiłem różne rzeczy ze słowem, dźwiękiem, obrazem i gestem oraz pomiędzy nimi. Być może nie wszyscy tu wyliczeni powiedzieliby o sobie, że są artystami p r y m a r n i e, ale niektórzy z pewnością (ja tak). Sądzę, że trzeba zasugerować możliwe różne motywacje: część ze wskazanych tu być może dzięki wejściu w styl queer pozwoliła sobie ośmielać swoje pisarstwo naukowe, ale część z nas z pewnością w y b r a ła queer (a nie np. studia gejowsko-lesbijskie) dlatego właśnie, że uważała, że może w ten sposób znieść ów fałszywy dualizm artyst(k)a-uczony(a) i wyrażać siebie, co wpisuje się w strategię upodmiotowienia opisaną w książce. Ów przeplot ról (o ile to dwie różne role) wydaje się differentia specifica nie tylko polskich badań queer względem zagranicznych czy w każdym razie amerykańskich, ale także względem innych nurtów w polskim literaturoznawstwie. 
przeformułowania języka akademickiej debaty poprzez tworzenie tekstów, w których wyraźne zaznaczanie podmiotowości piszącego/piszącej podważałoby tradycyjny model wypowiedzi naukowej. W polskiej krytyce queerowej tego rodzaju podejście chyba najwyraźniej manifestuje się w studiach Piotra Sobolczyka, co można zaobserwować m. in. w książkach "Queerowe subwersje..." oraz "Polish Queer Modernism" (Lisowska, 2019: 261) ${ }^{5}$.

Sama Katarzyna Lisowska natomiast nie pisze z pozycji podwójnej, aktantki i obserwatorki drugiego i trzeciego stopnia, jej książka oraz pozostały dorobek, jak podpowiada mi moje rozeznanie w literaturze przedmiotu poparte rzutem oka na bibliografię jej rozproszonych prac, pisany jest głównie z pozycji metaliteraturoznawczej. Samo w sobie z mojej perspektywy nie jest ani pozytywnym handicapem, ani ujmą, natomiast z pewnością to, że autorka nie dokonuje publicznych autorefleksji czy uzasadnień własnych wcześniejszych decyzji, zwalnia ją z zarzutów o narcyzm, egotyzm, badanie własnej twórczości, nieumiejętność zachowania granicy między podmiotem a przedmiotem badania - powyższa lista jest cytatem, nie moją inwencją zresztą. W ostatnich zdaniach książki Lisowska decyduje się wszak na pewną konfesję: „Przedstawione uwagi wynikają bowiem z wpływu dwóch uznawanych za w wielu punktach sprzeczne - metodologicznych fascynacji (a nawet miłości) piszącej te słowa: strukturalizmu i teorii queer" (Lisowska, 2019: 279). Co do inspiracji pierwszej, to istotnie z pewnością autorka dokonuje operacji t $\mathrm{m}$ e z y postulowanej w strukturalizmie (ale przecież nie tylko w nim) i analizuje dyskurs przede wszystkim przekrojowo; nie śmiem zaprzeczać miłościom, które śmieją wypowiedzieć swe imię, acz wydaje mi się, że co najmniej na równi uprawomocnione

${ }^{5}$ Również Tomasz Dalasiński w recenzji z moich Queerowych subwersji niejako "na własną rękę", to znaczy, nie posługując się pojęciem „autoetnografia”, wskazał na taki aspekt, konstruując udatny koncept autorski "(auto)mapowania”. Idem, (Auto)mapowanie queeru, "Teksty Drugie” 2016 nr 5, s. 146-153. Podobnie jak później Lisowska podnosi on także aspekt podważania akademickości wypowiedzi m.in. przez upodmiotowienie, literackość i kampowanie. (Tu warto przypomnieć o kontekście u Dalasińskiego nieobecnym, a podjętym przez Andy'ego Medhursta - kampu akademickiego: Uniwersytet - ze swoja absurdalna powaga otaczająca kwestie pozbawione realnego znaczenia, mitościa do wznoszenia gigantycznych superstruktur sensu na szczątkach i szczegółach, kultem pozycji i protokołu (...) - jest miejscem nader kampowym, idem, Kamp, przeł. P. Czaplinski w: Kamp. Antologia przekładów, red. P. Czapliński, A. Mizerka, Universitas, Kraków 2012, s. 139). Gwoli ścisłości należy wskazać, że różne tego rodzaju przeploty i figury jako "momenty” (podkreślam ich "wtrętowy” charakter) przydarzają się także u innych autorek i autorów, obecnych u Lisowskiej i nie, myślę o Izabeli Filipiak piszącej o Komornickiej w polilogu gatunkowym, Błażeju Warkockim (przede wszystkim w Różowym języku, ale i w Homo niewiadomo), a także u autora u Lisowskiej nieobecnego, Piotra Seweryna Rosoła w Genecie Gombrowicza, jakkolwiek być może ten ostatni niekoniecznie identyfikuje się z etykietą (niezależnie od tego jak antydyscyplinarnie nie chcielibyśmy jej widzieć) queer. Wydaje mi się, że tu trzeba poruszyć pewną kwestię zwykle w opisach pomijaną, a według mnie zafałszowującą obraz, jakkolwiek też wszystkim aktantom znaną, tylko uznawaną za niewypowiadalną. Otóż przy konstruowaniu opisów takich jak u Lisowskiej - to nie jest zresztą do niej zarzut - powstaje wrażenie, że aktanci mieli pełny wpływ na to, jak pisali i zależało to wyłącznie od ich woli. Tymczasem sam po sobie wiem, ile razy redakcje pism czy książek zbiorowych naciskały na usuwanie różnych postaci figur pisarskich, o których tu mówimy. Miałem wielkie szczęście, że Queerowe subwersje trafiły w do świetnej i obdarzonej poczuciem humoru redaktorki Basi Jędraszko, która wnet złapała i sens, i powiedzmy "wartość" rozmaitych tego rodzaju figur, podobnie zresztą jak rozumie to Lisowska (oraz Dalasiński; jakkolwiek byli i tacy, którzy wyrazili opór). Być może indywidualny temperament stylistyczny Śmiei czy Kaliściaka - co nic im nie ujmuje - po prostu nie rwie się ku takim rubieżom dyskursu i w ich wypadku - przypuszczam, nie wiem - jest to wybór indywidualny, ale w innych wypadkach nie zawsze temperament i kreatywność autorów spotykały się ze zrozumieniem, a bez zrozumienia tego obraz d y s k u r s u queer, rozumianego nie tylko jako tekst, ale i jego instytucje (więcej o tym powiem jeszcze dalej), zdaje się zbyt wygładzony i zbyt jednostkowo-liberalny, by tak rzec. "Upodomiotowienie", o którym pisze Lisowska, miało w dyskursie akademickim sens podobny, acz na innym poziomie, jak walka osób nienormatywnych o to, by powiedzieć w ł a s n y m językiem "jestem (tu)". 
jest uznanie autorki za kolejną reprezentantkę szkoły czy stylu myślowego wyprowacowanego we Wrocławiu, polskiego metaliteraturoznawstwa konstruktywistycznego, znaczonego nazwiskami Woj.ciecha Głowali, Wojciecha Solińskiego, Michaela Fleischera, Dominika Lewińskiego, Macieja Adamskiego, ich uczniów skupionych wokół już nieistniejącej inicjatywy Beobachter (Bogdan Balicki, Emil Szczerbuk, Bartosz Ryż i in.), Katarzyny Majbrody. W istocie książka Lisowskiej jest dla polskiej teorii queer (przede wszystkim) oraz gender takim wydarzeniem, jak - pozornie bliższa i przypisami wskazana - książka Katarzyny Majbrody dla polskiego feminizmu, ale także jest tym, czym książka Dominika Lewińskiego dla polskiego strukturalizmu. Co do drugiej części konfesji - wydaje mi się, że nie tylko moja własna "ślepa plamka" każe mi potwierdzić, że choć w książce badane są dyskursy genderowe, gejowsko-lesbijskie i queerowe, to właśnie te ostatnie z wyczuwalną największą pasją. I cóż w tym miałoby być złego? A rezultatem jest książka znakomita. Chcę zaznaczyć, aby być dobrze zrozumianym, że wszystkie moje uwagi, wskazujące, że coś można by dopowiedzieć, inaczej ująć, dodać inny poziom odniesień itp., nie są zarzutami do tej pracy, próbuję raczej mówić dwukierunkowo, jako komentator tej książki i dopowiadać pewne kwestie na rzecz samego tego dyskursu, wiedzy o nim, jako aktant, czyli z tej własnie "niewygodnej” (jakoby) pozycji i aktanta, i obserwatora drugiego, trzeciego stopnia.

Autorka precyzyjnie rozróżnia te trzy dyskursy: genderowy, gejowsko-lesbijski oraz queerowy, kompetentnie analizując odmienne nierzadko założenia za nimi stojące. W istocie cały pierwszy rozdział (Charakterystyka dyskursu genderowego w polskim literaturoznawstwie) uważam za w najlepszym tego słowa znaczeniu "podręcznikowy". Nawet jeżeli książka jako całość nie jest pełnym opisem polskiego literaturoznawstwa gender-queerowego - a być w założeniu nie miała - to w dużej mierze rolę tę spełnia. Pierwszy, bardziej opisowy rozdział świetnie dopełnia się tu z drugim, rzeczoną tmezą, analizą metafor w badanym dyskursie. Zanim o metaforach właśnie, chcę jeszcze zaznaczyć, że Lisowskiej udało się również trafnie wyłapać i wskazać na zarówno metodologiczne, stylistyczne, metaforyczne inspiracje myślą międzynarodową, głównie anglosaską - jak i na wkład własny, lokalne kontekstualizacje, adaptacje bądź pomysły twórcze, a nierzadko oba aspekty są gęsto w tych dyskursach zaplecione, również niektóre metafory literaturoznawcze brzmią równocześnie echem metafory zagranicznej, a jednocześnie słowiańską harmonią (debatować wówczas można o granicy: czy to "tylko” przeformułowanie? przesunięcie? czy też kanibalistyczne przepotwarzenie, wylinka?). Dla autorki jest to istotne jako problem przekładu, ale też jej ustalenia zaprzeczają wizji dyskursu - queerowego szczególnie - jako „aplikacji” zachodniej myśli do kontekstu odmiennego, "kolonialnej” fascynacji i powtarzania cudzej myśli i języka. Po części "tarczą obronną" przed "zakażeniem” językiem obcym, satanicznym nawiedzeniem językiem cudzym, jest wysoka świadomość metateoretyczna bohaterów i bohaterek książki. „Trzeba zarazem zwrócić uwagę na dużą świadomość metateoretyczną polskich autorów i autorek, doskonale zdających sobie sprawę zarówno z oddziaływania anglo-amerykańskich ujęć na rodzime studia, jak i z różnic pomiędzy oboma kontekstami akademickimi" (Lisowska, 2019: 94). Oraz: „te obiegowe motywy stylistyczne zyskują w obrębie interesujących mnie studiów cechy i znaczenia specyficzne dla danej perspektywy, a więc podlegają pewnemu rodzajowi przekładu kulturowego lub, co w tym kontekście może być stosowniejszym określeniem, metakrytycznego/ metodologicznego" (2019: 278). Ujmę rzecz jeszcze inaczej (i gradualnie): uważam, że polskie dyskursy gen- 
derowy i queerowy udatnie uniknęły, po pierwsze, efektu "odkrycia Ameryki", która już była odkryta (zarazem, przy wszelkich różnicach w szczegółach, w pewnym bardzo podstawowym aspekcie ludzka seksualność, w tym nienormatywne jej postaci, są bardzo podobne lub takie same ponadhistorycznie i ponadgeograficznie ${ }^{6}$ ); po drugie, umiejętnie włączyły się w język światowej humanistyki - czy, powiedzmy, zachodniej - potwierdzając, że możliwa jest płaszczyzna porozumienia i wymiany; wreszcie po trzecie, w najlepszych wypadkach nie ograniczyły się do jednokierunkowego „przekładu kulturowego metakrytycznego / metodologicznego", ale wymiana ta okazała się obukierunkowa, część oryginalnych polskich pomysłów oraz lokalnych ukontekstowień wykroczyła poza kontekst rodzimy, kontekst polskiego języka, akademii - co byłoby bardzo trudne, jeśli nie niemożliwe, gdyby nie istniała wcześniej owa „wspólna podstawa”, platforma uzgodnionych znaczeń wstępnych i heurystyk.

Główny trzon rozprawy, analityka metafor, także pozwala zrozumieć zasadnicze wątki polskiego i niekiedy międzynarodowego dyskursu gender-queerowego. Lisowska nie postępuje tu według procedur bardziej językoznawczych, nawet tych z zakresu analizy dyskursu, nie ogranicza się do "pocięcia” dyskursu na metaforyczne grupy i wyliczenia wariantów. W tej mierze wydaje mi się, że jej procedury wypadają ciekawiej niż modelowy w pewnej mierze projekt Olafa Jäkela ${ }^{8}$. Autorka dokonuje właściwie wglądów w teoretyczne czy filozoficzne zaplecze teorii queer poprzez wyróżnione metafory ${ }^{9}$. Oczywiście: tak pocięty obraz nie "sumuje się" do postaci podręcznikowej wykładni. Ale nie taki był cel tej pracy. Pewne natomiast, że kiedy podręcznikowe - czy hasłowe - ujęcie powstanie, z pewnością będzie się opierać na tych badaniach.

6 Podnosiłem tę kwestię we wstępie do Polish Queer Modernism (Frankfurt am Mein 2015, s. 7-15) pt. "Modernism. Polish. Queer". Mówiąc skrótowo: badania gejowsko-lesbijskie oraz queerowe nie „stworzyły” homoseksualności. W duchu Foucaultowskim można by mówić, że stworzyła ją XIX-wieczna medycyna przy współudziale prawa - oczywiście w sensie instytucjonalnym i dyskursywnym. Nawet najbardziej gorliwy zwolennik kontekstu lokalnego domagającego się oryginalności odciętej od źródeł międzynarodowych nie może nie wziąć pod uwagę, że w chwili, gdy owe nowe tożsamości seksualne były dyskursywnie i instytucjonalnie kształtowane, co współgra zresztą z wyłonieniem się modernizmu, „polska tożsamość" była poddana wpływom trzech dyskursów narodowych i ich instytucji (bardzo zresztą różnie podchodzących do kwestii seksualności, co też wynikało z oparcia tych trzech kultur na trzech różnych instytucjach religijnych: protestantyzmu, prawosławia i katolicyzmu), z którymi negocjowała swój własny (zależnościowy) dyskurs. Polska homoseksualność instytucjonalna nie zaczęła się w 1918, a też tylko do pewnego stopnia sformalizowała się w 1932. Czasami natomiast można odnieść wrażenie, że postulatorzy „oryginalnej i odciętej od obcych kontekstów” wiedzy o polskiej (homo)seksualności w gruncie rzeczy fantazjują o tym, że po takowej ejdetyce okaże się, iż może owej homoseksualności nigdy nie było. Otóż nie okaże się.

${ }^{7}$ A przecież, przynajmniej deklaratywnie, takie "umiędzynarodowienie" polskich badań jest instytucjonalnie postulowane.

8 O. Jäkel, Metafory w abstrakcyjnych domenach dyskursu. Kognitywno-lingwistyczna analiza metaforycznych modeli aktywności umysłowej, gospodarki i nauki, przeł. M. Banaś, B. Drąg, Universitas, Kraków 2003.

${ }^{9}$ Posługuje się też metodą nie ilościową, a jakościową - dobiera metafory jako exempla, nie zależy jej natomiast na wyliczeniu wszystkich rozpoznanych ujęć danej metafory w dyskursie. I słusznie. Jeżeli można by tu wystąpić z pewną wątpliwością czy zastrzeżeniem co do analizy metafor, to brzmiałoby ono tak: nie zawsze autorka odróżnia, by tak rzec, stopień upodmiotowienia metafory, to znaczy - czy wypowiada ją we własnym imieniu badacz(ka), załóżmy Wojciech Śmieja czy Błażej Warkocki, czy też jako komentarz do badanego pisarza czy pisarki, a tu z kolei czy wyczytuje obecność takiej metafory u pisarza czy pisarki X, czy też ją wczytuje a) na podstawie obserwacji jakkolwiek upotocznionej, czy b) wczytuje metaforę wyczytaną w cudzych badaniach jako alegorię czytania (czyli, upraszczając, czy dajmy na to Błażej Warkocki wczytuje w Stasiuka jako alegorię czytania gotycystyczną literaturę odczytaną przez Sedgwick). W paru miejscach Lisowska zaznacza, że użycie danej metafory służy wyrażeniu światopoglądu badacza (por. s. 214 - o mnie, 240 - o Warkockim), ale na ogół jest to rozmyte. Co prawda sądzę, że każdy aktant, każdy z wnętrza dyskursu queerowego, będzie wiedział, co w jakiej modalności zostało wypowiedziane. 
Można by zresztą postawić pytanie, czy dyskurs - queerowy zwłaszcza - musi lub może się w ogóle "sumować", będąc polilogicznym, wewnętrznie agonicznym, zarówno na poziomie makro jak i mikro projektem, projektami. Warto zatem raczej - przechodzę do kilku wątpliwości czy pytań - zastanawiać się, czy z jednej strony wyniki Lisowskiej nie sumując się, nie budując kompletnego przeglądu dotychczasowego stanu tych badań, nie wytwarzają jednocześnie efektu nadmiernie ich homogenizującego. Autorka jest świadoma tego ryzyka i pogłębianie komentarzy do poszczególnych metafor czy ujęć po części ją uchrania przed zarzutem, że badania rozmaitych aktantów wypadają jako dosyć podobne dlatego, że autorka podniosła tylko to, co w nich podobne (pamiętamy jeszcze, że taki zarzut często formułowano wobec niektórych postaci strukturalizmu). Problemem, który nie może być zarzutem do autorki, ale z mojej perspektywy jest niezbędny do dopowiedzenia, jest nieuwzględnienie w tej rozprawie aspektu instytucjonalnego jako części metaliteraturoznawstwa. Oczywiście nie każde metaliteraturoznawstwo tak pojmuje dyskurs. Tak jak - przeglądając różne stanowiska - Foucault, Bourdieu, Kuhn, socjologia wiedzy, oraz co ja sam próbowałem robić, a z pewnością postulowałem, konstruując własny program dyskursywizowania i recepcji ${ }^{10}$. W dodatku Lisowska wyraźnie zaznacza w tytule i opisie założeń, że interesuje ją pewien aspekt dyskursu (jego metaforyczność), nie dyskurs jako taki. Natomiast na użytek wiedzy, także jakichś przyszłych syntez, warto o badaniach - queerowych w każdym razie - powiedzieć co najmniej dwie następujące rzeczy, wynikające z rozpoznania dyskursu nie jako samej „treści”, enuncjacji, tego, co wypowiedziane, ale i z punktu widzenia instytucji produkujących (oraz blokujących) dyskursy. Wbrew wrażeniu, jakie po lekturze rozprawy się narzuca, jednak powstanie nurtu queerowego w polskiej akademii, w tym literaturoznawstwie, było szeregiem projektów indywidualnych, o ile nie wręcz nomadycznych. Wyjątkami tu są w zasadzie tylko Wojciech Śmieja i Tomasz Kaliściak, obaj z Uniwersytetu Śląskiego, obaj uczniowie Krzysztofa Kłosińskiego. W wypadku pozostałych - nas - były to projekty indywidualne i z gruntu, pozwolę sobie na taką metaforę, "bezojcowskie”, "niepępowinowe”; co nie znaczy, że nie szukaliśmy w instytucji wyżej postawionych otwartych sojuszników, aby projekty te udawało się przeprowadzić. Konferencje, na których spotkała się większość omawianych przez Lisowską aktantów, a też nie wszyscy, przydarzyły się tylko $\mathrm{dwie}^{11}$. Z całą pewnością więc nie można widzieć tego nurtu jako tak silnie sparadygmatyzowanego instytucjonalnie jak np. był strukturalizm w Polsce, ale też i z nurtów późniejszych, feminizm. W istocie argumentowałbym, iż pewna nomadyczność i idiosynkratyczność queer są jego zasadniczą jakością, czy nawet strategią. Sprawa druga, dużo bardziej podatna na tabuizowanie (a więc bardziej „skandalizująca", wbrew intencjom piszącego zresztą) to opór instytucjonalny, jaki towarzyszył i towarzyszy

10 W książkach Dyskursywizowanie Białoszewskiego, t. I Słowo/Obraz Terytoria, Gdańsk 2013, t. II Słowo/Obraz Terytoria, Gdańsk 2014 - o czym wspominam także dlatego, że Lisowska się na moją propozycję powołuje, jakkolwiek, co nieco zabawne, bez połączenia Sobolczyka-teoretyka z bohaterem książki, jakby to były dwie różne osoby. Może i zresztą były?

${ }^{11}$ Pierwsza to Lektury ptci. Polskie (kon)teksty, Warszawa (UW), marzec 2008. Obecni byli: Tomasz Kaliściak, Tomasz Kitliński, Piotr Sobolczyk, Wojciech Śmieja, Błażej Warkocki oraz wzmiankowany incydentalnie przez Lisowską Robert Cieślak, ponadto autorki omawiane w Metaforyczności... jako reprezentantki studiów genderowych (i feministycznych) Inga Iwasiów i Bożena Chołuj. Druga to Nieheteronormatywność. Narracje, praktyki, przedstawienia, Toruń (UMK) 2-4 XII 2015. Obecni byli: Tomasz Kaliściak, Piotr Sobolczyk, Wojciech Śmieja, Błażej Warkocki. Z opisywanych przez Lisowską autorek i autorów nie było Izabeli Filipiak, Pawła Leszkowicza, Tomasza Kitlińskiego. Materiały z tej sesji jak dotąd nie ukazały się drukiem. Warto zauważyć, że w marcu 2008 z omawianych przez Lisowską autorów queerowych tylko Warkocki i Kitliński byli autorami publikacji książkowej z zakresu queer, ale zasadnie rzec można, że wszyscy wówczas dopiero zaczynaliśmy czy "rozkręcaliśmy się". 
instalowaniu się queer - znów: przede wszystkim queer właśnie - w akademii, rzecz, której zupełnie nie można odczuć z opisu Lisowskiej, co nie jest do niej zarzutem. Podobnie jednak jak opis strukturalizmu bez uwzględnienia sytuacji w ówczesnej akademii, szczególnie bez opisu oporowego charakteru tej formacji wobec marksizmu, jest niepełny (a też owe instytucjonalne aspekty odciskają się i na stylistycznej, tekstowej, konstrukcyjnej stronie dyskursów, co daje się wyczytać), tak i trudno zrozumieć historię, a nawet stylistykę queer bez takiego odniesienia. I tak trzeba zwrócić uwagę na trudności, jakie bohaterowie i bohaterki książki Lisowskiej mieli w uzyskaniu zatrudnienia: Błażej Warkocki czekał na nie trzy lata, ja cztery, Wojciech Śmieja nim wrócił na macierzysty UŚ przez lata wykładał w Wyższej Szkole Zarządzania Ochroną Pracy w Katowicach, Barbara Czarnecka - parokrotnie wzmiankowana w rozprawie Lisowskiej autorka monografii Lechoń homotekstualny - po habilitacji straciła pracę na macierzystym UMK. Również uzyskiwanie stopni naukowych bywało problematyczne: Izabeli Filipiak odmówiono nadania stopnia doktora (jej pracę o Komornickiej wysoko ceni Lisowska, ja uważam podobnie za wybitną); Piotr Seweryn Rosół, autor wybitnej rozprawy o Gombrowiczu i Genecie, pierwotnie obronił ją na Sorbonie, ale w ramach umowy co-tutelle polska strona odmówiła mu nadania tego stopnia; Tomaszowi Kitlińskiemu i mnie odmówiono nadania stopnia doktora habilitowanego - w każdym z tych wypadków wyższa instancja (Centralna Komisja) unieważniała te decyzje. Trudno mi uznać, że to są pojedyncze incydenty i przypadkowo "tak wyszło", a nie że jest to jednak pewien paradygmat (paradygmat reakcji, nie "spisek", dla jasności). Ponieważ końcówka tej recenzji minorowym a dysonansowym akordem zabrzmiała, próbując sztuki kontrapunktu powiem finalnie w imieniu swoim i, jak sądzę, innych bohaterek i bohaterów, że książkę Katarzyny Lisowskiej, tak świetnie rozumiejącej nasze pomysły i dążenia, odbieramy jako nagrodę.

\section{Bibliografia}

Dalasiński, Tomasz (2016), "(Auto)mapowanie queeru”, Teksty Drugie, 5: 146-153, https://doi.org/10.18318/td.2016.5.9

Iwasiów, Inga (2004), Parafrazy i reinterpretacje. Wykłady z teorii i praktyki czytania, Szczecin, Wyd. Naukowe Uniwersytetu Szczecińskiego.

Jäkel, Olaf (2003), Metafory w abstrakcyjnych domenach dyskursu. Kognitywno-lingwistyczna analiza metaforycznych modeli aktywności umysłowej, gospodarki i nauki, przeł. Monika Banaś, Bronisław Drąg, Kraków, Universitas.

Lisowska, Katarzyna (2019), Metaforyczność w dyskursie genderowym polskiego literaturoznawstwa po 1989 roku, Kraków, Universitas.

Majbroda, Katarzyna (2013), Feministyczna krytyka literatury w Polsce po 1989 roku. Tekst, dyskurs, poznanie z odmiennej perspektywy, Kraków, Universitas.

Medhurst, Andy (2012), "Kamp”, przeł. P. Czaplinski, Kamp. Antologia przekładów, Przemysław Czapliński, Anna Mizerka (red.), Kraków, Universitas: 118-143.

Sikora, Tomasz i Rafał Majka, "Teorie odmieńcze”, Teorie wywrotowe. Antologia przekładów, Agnieszka Gajewska (red.), Poznań, Wyd. Poznańskie: 599-604.

Sobolczyk, Piotr (2013), Dyskursywizowanie Białoszewskiego, t. I, Gdańsk, Słowo/Obraz Terytoria. . (2014), Dyskursywizowanie Białoszewskiego, t. II, Gdańsk, Słowo/Obraz Terytoria.

(2015), Polish Queer Modernism, Peter Lang, Franfurt am Mein. 